\title{
Effects of Financial Education and Impulsive Buying on Saving Behavior of Korean College Students
}

This study examined how financial education, impulsive buying, and socio-demographic factors affect saving behavior of 500 Korean college students. The descriptive results show that students who received financial education reported more positive saving behavior compared to students who did not receive financial education in school. The OLS results indicate that all else being equal, students with financial education reported more positive saving behavior than those without financial education. As predictors of saving behavior among Korean college students, the OLS results also reveal that impulsive buying, gender, and age were statistically significant. This study concludes that receiving financial education early, such as in elementary school, plays an important role in determining the saving behavior of Korean college students.

Money attitudes and behaviors have been studied by researchers from a wide range of disciplines employing different theoretical approaches and methodologies. Researchers want to know what factors shape money attitudes and behaviors. Consumer educators are interested in understanding factors that influence money attitudes in order to promote positive behaviors. Attitudes toward savings

Associate Professor, Department of Family, Consumer, and Human Development, Utah State University (yoon.lee@usu.edu)

${ }^{\star}$ Professor, Department of Family, Consumer, and Human Development, Utah State University (jean.lown@usu.edu)

Key Words: college students, financial education, impulsive buying, and saving behavior predict financial problems; therefore, financial education is needed to encourage positive saving behaviors (Dowling, Corney, \& Hoiles, 2009). Despite extensive literature on money attitudes and behaviors, the growing body of research has mostly overlooked the potential effects of financial education and money behavior on saving attitudes and behaviors.

Since World War II, South Korea has rapidly evolved from a poor rural country to an economic powerhouse, from a recipient of foreign aid to a donor nation, from a net importer of goods to a premier exporter of automobiles and electronics, culminating its growing role in the world economy by hosting the G-20 summit in 2010 (Ramstad, 2010). South Korea is one of the "emergent consumer markets" of rapidly growing countries (Burgess, 2005), yet little research has examined money and saving behavior in Korea where a world economic power is emerging. During the 2000s, Korea's household savings rate decreased rapidly, while household debt increased (Chung, 2008). Since savings rate in Korea has decreased from $24 \%$ in 1987 to $3.1 \%$ in 2011 (Plummeting Savings Rate, 2012), it is important to understand the money and saving behaviors of college students who are the future of the Korean economy.

Using data collected in 2007 with a saving scale and an impulsive buying scale (Sybrowsky, 2007), this study focused on the effects of financial education and impulsive buying on saving behavior. 
This study further investigated the role of sociodemographic and family factors. While understanding factors associated with saving behaviors of Korean college students, it is hoped that the findings of this study would help financial educators and policymakers target sub-groups with different social, family, and financial knowledge backgrounds when they design financial education programs for use in public schools.

\section{Research on Money Attitudes around the World}

While money attitude research started in English speaking countries, research is expanding around the world. Using the Yamauchi and Templer's Money Attitude Scale (MAS) in Mexico, Roberts and Sepulveda (1999) reported a distinct relationship between demographics and money attitudes. Lynn (1993) explored money attitudes in 20 nations, reporting significant gender differences, concluding that males are more competitive and concerned with money than females. In Australia, gender was the most powerful variable influencing money attitudes about the future, with women significantly more worried than men (Adams, Lown, \& Bailey, 1994). Burgess (2005) studied urban South Africans, one of the "emergent consumer markets," concluding "that money attitudes and value priorities have predictable and theoretically meaningful relations"(p.106).

Studies conducted in the United States, Canada and Australia (Adams et al. 1994; Bailey \& Lown, 1993) concluded that money attitudes differed in the three English-speaking nations. A study of money attitudes and financial problems among young Australian males (Dowling et al. 2009) found that "financial management practices and money attitudes significantly predicted financial problems. Financial management practices, money attitudes, and financial problems also significantly predicted financial satisfaction" (p. 5).

Researchers studying money attitudes and spending habits of American college students universally support the need for financial management education with an emphasis on responsible credit card use (Hayhoe, Leach, \& Turner, 1999; Moore \& Carpenter, 2009; Norvilitis et al. 2006). Özgen and Bayolu (2005) reported age and gender differences in money attitudes among Turkish college students. In addition, they documented that over half the students worried about not having enough money, not being able to make ends meet, and not being able to graduate due to finances.

Masuo, Kim, Malroutu, and Hanashiro (2002) compared the money attitudes of female Asian and Asian-American college students, concluding that Asian female students view money in a more symbolic way compared to the pragmatic views of Asian-American female students. In a study of students in Korea, Japan, and the United States, Masuo, Malroutu, Hanashiro, and Kim (2004) reported that Asian students believe that "money can solve all problems" (p. 476), while their AsianAmerican counterparts are more private about their finances.

Faber and O'Guinn (1992) developed a Compulsive Buying Scale to examine this unhealthy behavior. Using this scale, Roberts and Jones (2001) explored money attitudes, credit card use, and compulsive buying among American college students. Spinella, Yang, and Lester (2007) reported a strong correlation between money attitudes and compulsive buying, illustrating a practical application of money attitude research. Beyond simply assessing and measuring attitudes to better understand human behavior, the tools can be used to address problematic spending behaviors. Because compulsive buying typically involves overspending and the use of credit, it is expected that persons who score high on compulsive buying would not be savers.

\section{Research on Money Attitudes in Korea}

Kim and Jeoung (1996) examined the money attitudes of Korean university students and reported different factor loadings compared to studies with English speaking subjects. Similar to the results of Masuo et al. (2002), Korean students held more conceptual attitudes toward money compared to the pragmatic views of British subjects (Kim \& Jeoung, 1996). A sample of English-speaking college students in Singapore, who held Chinese values and cultural perspectives, revealed that students in Singapore expressed different views on money than subjects from other cultures (Lim \& Teo, 1997). 
While comparing money and credit attitudes of housewives and female college students in Korea, J. Kim (2002) found that housewives perceive money as security while female students tend to view money as an emotional tool. In a study of money attitudes and behaviors of Korean college students, $\mathrm{H}$. Kim (2005) reported that gender, grade, mother's and father's profession, and mother's education significantly affected the financial management behaviors of college students. Jung and Yoon (2008) identified six different money attitudes among Korean undergraduate students. The six attitudes were money as a means of seizing power, a life pursuit, a tool for rational consumption, a barometer of success, a cause of anxiety, and a source of distrust. These researchers found significant differences in money attitudes based on gender, college major, age, and allowance amount.

Hong (2005) examined the effect of money attitudes on spending behaviors of middle, high school, and college students in Korea, reporting that impulsive spending behaviors are influenced by age, gender, and self-esteem. Y. Kim (2005) investigated factors affecting financial management practices of Korean college students, reporting that their financial management practices were affected by their year in college, whether they were living with their parents, the amount of their allowance, and whether they had taken a personal financial management course. The author noted that students who studied financial management in college reported more positive financial management practices than their peers who had not studied personal finance (Y. Kim, 2005). No studies on impulsive buying attitudes in Korea were identified.

\section{Money Attitudes, Behaviors and Demographics}

Numerous studies have demonstrated demographic differences in money attitudes, especially based on gender (Adams et al., 1994; Gresham \& Fontenot, 1989; H. Kim, 2005; Tang, 1992, 1993). Taiwanese university students differed in their money attitudes and behaviors based on age (Tang, 1992, 1993). Research in Korea and other countries suggests that family of origin (education and occupation of parents and family income), living in a metropolitan area versus a less urban area, with less exposure to shopping opportunities, may affect saving attitudes and behaviors (Jung \& Yoon, 2008; J. Kim, 2002; Y. Kim, 2005). Based on previous studies, it is expected that being female, older, having parents with higher levels of education, having higher family income, and living in larger cities are positively related to saving attitudes and behaviors (Gresham \& Fontenot,1989; Hong, 2005; Jung \& Yoon, 2008; Y. Kim, 2005).

Previous studies reveal that money attitudes and behaviors differ across cultures as well as by demographics. Not surprisingly, studies show that Asian university students hold different money attitudes compared to ethnic Asians in other countries, as well as compared to Caucasian students in English speaking countries. High saving rates and materialistic values are prevalent in East Asian societies (Tung \& Baumann, 2009), yet these two values could be viewed as counter balancing influences with materialism reducing savings rates. As the middle class expands in Asia, and the world economy becomes globalized, it is important to understand the saving behaviors of Korea's young adults.

To examine the saving behavior of the next generation of Korean consumers and leaders, the following two major hypotheses were tested in this study: 1) Financial education is positively related to saving behavior (H1); 2) Impulsive buying is negatively related to saving behavior (H2). This study also hypothesized that demographic factors such as being female (H3), older (H4), having highly educated parents (H5), higher family income (H6), and living in larger cities (H7) are positively related to more constructive saving behavior among Korean college students.

\section{METHODS}

\section{Data}

An 8-item Saving Scale (Sybrowsky, 2007) was used to measure saving attitudes and behaviors. Impulsive buying was measured by the Impulsive Buying Scale (Sybrowsky, 2007), a variation on Faber and O'Guinn's 
(1992) Compulsive Buying Scale. Sybrowsky (2007) explained that he chose "the terminology of impulsive buying based on the argument of Edwards (1993) that compulsive buying is a clinically diagnosable disorder, while impulsive buying is a type of behavior" (p. 10). Since the current study examined a general college student population, and not a clinical sample, the term "impulsive buying" is appropriate. Surveys were administered to 501 undergraduate students attending seven public universities in South Korea. The universities were located in the Seoul, Gyeonggi-do, Chungcheong-do, Gangwon-do, Gyeongsang-do, and Jeonra-do areas. Participants responded online to a questionnaire that took approximately 10 minutes.

\section{Analyses}

Percentages, means, and medians were calculated to describe the sample. Chi-square tests compared demographic characteristics of students with financial education $(n=236)$ to those without $(n=264)$. T-tests compared mean differences in impulsive buying and saving behaviors of students with financial education to those without. Ordinary Least Squares (OLS) regression analyses were used to identify factors associated with saving behavior.

\section{Variables}

The dependent and explanatory variables are presented in Table 1. The dependent variable was an 8-item Saving Scale (Sybrowsky, 2007): 1) I felt that saving money was important; 2) I made a point to save somof the money I received; 3) I have money in savings; 4) I saved money from my summer earnings; 5) I saved money in a savings/checking account; 6) I added money to my savings regularly; 7) I lived within my income; and 8) I paid my bills on time. Responses were recorded on a 5-point scale ranging from 1 (never), 2 (seldom), 3 (sometimes), 4 (frequently), to 5 (always). The Cronbach's alpha was high (.85). The sum of response to the eight items was the dependent variable in the OLS model.

In the OLS regression analysis, financial education experience was used to predict saving behavior. The variable was based on the question: "Have you ever received financial education?” A binary variable ( 1 if respondent had financial education; 0 if otherwise) was included in the empirical model. Using this variable, Hypothesis1- Financial education would be positively influence saving behavior, was examined.

As another explanatory variable, an impulsive buying index was included in the OLS models. Sybrowsky's (2007) Impulsive Buying Scale was designed to explore the behaviors, motivations, and feelings associated with impulsive spending. The scale contained six items: 1 ) If I had money was left over, I just had to spend it; 2) I felt others would be horrified if they knew of my spending habits; 3) I bought things even if I really could not afford them; 4) I bought myself things to make myself feel better; 5) My parents would have been shocked if they knew how I spent money; and 6) I felt anxious or nervous on days I did not go shopping. Responses to each item could range from 1 (never) to 5 (always) on the 5-point scale. Cronbach's alpha for impulsive buying index was .80. Using this index variable, Hypothesis 2 - impulsive buying would negatively influence levels of saving behavior - was examined.

Gender and age of the respondents were included in the empirical models. To examine the effect of gender on saving behavior, two dummy variables (females; reference group, males) were included. Age of the respondent was divided into three categories: age18-20 (reference group), age 2124, and age 25-29. Dummy variables for parents' education levels were included in the analyses: high school education and college education (reference group). Most Korean college students live with their parents, are unlikely to work for pay, and are financially dependent. Thus, it is assumed that parents' education would influence students' saving behavior because parents with higher levels of education may have more financial knowledge to help their children understand the outcomes of saving or borrowing behavior. Other variables included in the empirical models were relative family income and residential area. Three dummy categorical variables for family income were: average, above average, and below average (reference group). Two dummy variables for residential region [SeoulGyeonggi, non-Seoul (reference group)] were included in the empirical models. 
Table 1. Measurement of Variables and Summary Statistics of Sample (N=500)

\begin{tabular}{|c|c|c|}
\hline Variables & Measurement & $\begin{array}{l}\text { Mean (Median) } \\
\text { Frequency }(\%)\end{array}$ \\
\hline \multicolumn{3}{|l|}{ Explanatory Variables } \\
\hline \multicolumn{3}{|l|}{ Financial Education: } \\
\hline $\mathrm{Had}$ & 1 if $\mathrm{R}$ had financial education, 0 if otherwise & $264(52.8 \%)$ \\
\hline (Not had) & 1 if $\mathrm{R}$ had no financial education, 0 if otherwise & $236(47.2 \%)$ \\
\hline Impulsive Buying & Continuous, sum of responses to 6 items (range $=6-30$ ) & $12.5(12.0)$ \\
\hline \multicolumn{3}{|l|}{ Personal Characteristics } \\
\hline \multicolumn{3}{|l|}{ Gender: } \\
\hline Males & 1 if male respondents, 0 if otherwise & $250(50.0 \%)$ \\
\hline (Females) & 1 if female respondents, 0 if otherwise & $250(50.0 \%)$ \\
\hline Age: & & $22.6(22.5)$ \\
\hline 1 if $\mathrm{R}$ age $18-20$ & 1 if respondent age $18-20,0$ if otherwise & $148(29.6 \%)$ \\
\hline 1 if $\mathrm{R}$ age $21-24$ & 1 if respondent age $21-24,0$ if otherwise & $200(40.0 \%)$ \\
\hline 1 if $R$ age $25-29$ & 1 if respondent age $25-29,0$ if otherwise & $152(30.4 \%)$ \\
\hline \multicolumn{3}{|c|}{ Family/Social Background } \\
\hline \multicolumn{3}{|l|}{ Father's education: } \\
\hline High school education & 1 if less than high or high school, 0 if otherwise & $316(63.2 \%)$ \\
\hline (College education) & 1 if some college or college graduate, 0 if otherwise & $184(36.8 \%)$ \\
\hline \multicolumn{3}{|l|}{ Mother's education: } \\
\hline High school education & 1 if less than high or high school, 0 if otherwise & $402(80.4 \%)$ \\
\hline (College education) & 1 if some college or college gradute, 0 if otherwise & $98(19.6 \%)$ \\
\hline \multicolumn{3}{|l|}{ Family income: } \\
\hline (Below average) & 1 if $\mathrm{HH}$ income below average, 0 if otherwise & $157(31.4 \%)$ \\
\hline Average & 1 if $\mathrm{HH}$ income about average, 0 if otherwise & $240(48.0 \%)$ \\
\hline Above average & 1 if $\mathrm{HH}$ income above average, 0 if otherwise & $103(20.6 \%)$ \\
\hline \multicolumn{3}{|l|}{ Residential area: } \\
\hline Seoul-Gyeonggi & 1 if $\mathrm{R}$ lives in Seoul or Gyeonggi, 0 if otherwise & $173(34.6 \%)$ \\
\hline (Other areas) & $\begin{array}{l}1 \text { if } \mathrm{R} \text { lives in Chungcheong, Gangwon, Gyeongsang, or Jeonra areas, } \\
0 \text { if otherwise }\end{array}$ & $327(65.4 \%)$ \\
\hline \multicolumn{3}{|l|}{ Dependent Variable } \\
\hline Saving Behavior & Continuous, sum of responses to 8 items (range $=11-40$ ) & $29.5(30.0)$ \\
\hline
\end{tabular}

Note. () represent reference groups in multivariate analyses.

\section{RESULTS}

\section{Sample Characteristics}

Table 1 provides descriptive information for the sample. Only one questionnaire was unusable, resulting in a sample size of 500. Half $(\mathrm{n}=250)$ the students were male and half $(\mathrm{n}=250)$ female, ranging in age from 18 to 29 (mean=22.6, median=22.5). More students were from the other areas than the
Seoul-Gyeonggi metropolitan area. The mean saving score was 29.5 (range $=11$ to 40 ). The mean impulsive buying score was 12.5 (range $=6$ to 30 ). About $53 \%$ of the students reported that they had some financial education.

Parents' education, family income, and residential area comprise the family and social background. Table 1 shows that $36.8 \%$ of fathers and $19.6 \%$ of mother had some college education or a college 
Table 2. Sample Characteristics by Financial Education Experience

\begin{tabular}{|c|c|c|c|}
\hline Variables & $\begin{array}{l}\text { Had Financial } \\
\text { Education } \\
(\mathrm{n}=264)\end{array}$ & $\begin{array}{l}\text { Not Had Financial } \\
\text { Education } \\
(\mathrm{n}=236)\end{array}$ & $\underset{\text { t-tests }}{\chi^{2}}$ \\
\hline \multicolumn{4}{|l|}{ Personal Characteristics } \\
\hline \multicolumn{4}{|l|}{ Gender: } \\
\hline Males & $54.9 \%$ & $44.5 \%$ & $\chi^{2}=5.43^{*}$ \\
\hline Females & $45.1 \%$ & $55.5 \%$ & \\
\hline \multicolumn{4}{|l|}{ Age: } \\
\hline Age $18-20$ & $30.3 \%$ & $28.8 \%$ & $\chi^{2}=5.21^{+}$ \\
\hline Age 21-24 & $43.6 \%$ & $36.0 \%$ & \\
\hline Age $25-29$ & $26.1 \%$ & $35.2 \%$ & \\
\hline \multicolumn{4}{|l|}{ Family/Social Background } \\
\hline \multicolumn{4}{|l|}{ Father's education: } \\
\hline High school education & $61.7 \%$ & $64.8 \%$ & $\chi^{2}=0.51$ \\
\hline College education & $38.3 \%$ & $35.2 \%$ & \\
\hline \multicolumn{4}{|l|}{ Mother's education: } \\
\hline High school education & $79.2 \%$ & $81.8 \%$ & $\chi^{2}=0.54$ \\
\hline College education & $20.8 \%$ & $18.2 \%$ & \\
\hline \multicolumn{4}{|l|}{ Perceived family income: } \\
\hline Below average & $29.2 \%$ & $33.9 \%$ & $\chi^{2}=2.12$ \\
\hline Average & $48.1 \%$ & $47.9 \%$ & \\
\hline Above average & $22.7 \%$ & $18.2 \%$ & \\
\hline \multicolumn{4}{|l|}{ Residential area: } \\
\hline Seoul-Gyeonggi & $34.5 \%$ & $34.7 \%$ & $\chi^{2}=0.004$ \\
\hline Other areas & $65.5 \%$ & $65.3 \%$ & \\
\hline Impulsive Buying Index (Cronbach's alpha $=.80)$ & 11.7 & 12.1 & $\mathrm{t}=-1.10$ \\
\hline 1) If I had money was left over, I just had to spend it & 2.5 & 2.6 & $\mathrm{t}=-1.65^{+}$ \\
\hline 2) Others would be horrified if they knew my spending habits & 2.0 & 2.0 & $\mathrm{t}=-0.35$ \\
\hline 3) I bought things even if I really could not afford them & 1.8 & 1.9 & $\mathrm{t}=-1.63^{+}$ \\
\hline 4) I bought myself things to make myself feel better & 2.4 & 2.6 & $\mathrm{t}=-2.51 * *$ \\
\hline 5) My parents would be shocked if they knew my spending & 2.2 & 2.1 & $\mathrm{t}=0.94$ \\
\hline 6) I felt anxious or nervous on days I didn't go shopping & 1.4 & 1.4 & $\mathrm{t}=0.61$ \\
\hline Saving Scale Index (Cronbach's alpha $=.85$ ) & 30.4 & 28.5 & $\mathrm{t}=-3.28 * * *$ \\
\hline 1) I felt saving money was important & 4.4 & 4.3 & $\mathrm{t}=2.13^{*}$ \\
\hline 2) I made a point to save some of the money I received & 4.1 & 3.9 & $\mathrm{t}=2.99 * *$ \\
\hline 3) I have money in savings & 3.6 & 3.3 & $\mathrm{t}=2.14^{*}$ \\
\hline 4) I saved money from my summer earnings & 3.9 & 3.6 & $\mathrm{t}=2.85^{* *}$ \\
\hline 5) I saved money in a saving/checking account & 3.6 & 3.3 & $\mathrm{t}=1.70^{+}$ \\
\hline 6) I added money to my savings regularly & 3.0 & 2.6 & $\mathrm{t}=4.13 * * *$ \\
\hline 7) I lived within my income & 3.7 & 3.7 & $\mathrm{t}=.074$ \\
\hline 8) I paid my bills on time & 4.1 & 3.9 & $\mathrm{t}=1.46$ \\
\hline
\end{tabular}
${ }^{+} p<.10 ;{ }^{*} p<.05 ; * * p<.01 ; * * * p<.001$

degree. About $48 \%$ identified their family income as average, with $20.6 \%$ above and $31.4 \%$ below average.
More than half reported living in the Chungcheongdo, Gangwon-do, Gyeongsang-do, and Jeonra-do areas, 
while $34.6 \%$ resided in the Seoul-Gyeonggi area.

\section{Demographic Profiles of Students and Financial Education}

Table 2 provides descriptive information on personal characteristics, family and social background of those who had financial education $(n=264)$ and those who had no formal financial education $(n=236)$. The Chi-square test for independence shows that the two groups differed significantly by gender and age. Table 2 reveals that students with financial education tended to be male, age 21-24, had parents with a high school education, reported average family income, and were in other areas. Students age 18-20 and 21-24 were more likely than students ages 25-29 to report financial education experience.

Students with financial education reported college educated parents, while the non-education group reported less educated parents. For both groups, most students reported their family income as "average." However, a higher proportion of the non-education group reported their family income as "below average," while the education group reported their family income as "above average."

\section{Financial Education, Saving, and Impulsive Buying}

As shown in Table 2, the t-test reveals a significant mean difference in the index of saving behavior between students with and without financial education experience. The higher the saving scale scored, the more positive the behavior. Overall, students who had financial education scored higher on most items. Except for living within income and paying bills on time, respondents with financial education scored higher on the other items: e.g., importance of saving money; making a point to save money; having money in savings; saving money from summer earnings; contributing to a saving account; and adding money to savings regularly.

Table 2 also reveals that the mean level of the impulsive buying index was higher for the nonfinancial education group. Although descriptive statistics indicate that three of the six items show significant mean differences between the two education groups, the mean difference in the total impulsive buying index was not statistically significant.
Compared to students with financial education, students who did not have financial education reported higher scores on the following items: I just had to spend it, I bought things when I could not afford, and I bought things to feel better. It is evident in Table 2 that the money behavior of Korean college students with and without financial education differed regarding impulsive buying and saving behavior.

\section{OLS Results: Predictors of Saving Behavior}

Financial education experience, impulsive buying, gender, age, father's education, mother's education, family income, and residential area were entered in the OLS regression analysis for the total sample. This research hypothesized that having financial education is positively related to saving behavior (H1). The OLS results show that all else being equal, the coefficient associated with financial education was statistically significant and positive, indicating that college students with financial education had more positive saving behavior, supporting Hypothesis 1. The OLS results show that there was a negative relationship between impulsive buying and saving behavior. As the level of impulsive money behavior increased, the saving scores decreased, indicating that higher levels of impulsive buying negatively influence saving behavior, supporting Hypothesis 2 .

This study also hypothesized that personal and family/social factors are related to the saving behaviors of Korean college students. Table 3 reveals that factors such as parents' education, family income, and residential area were not statistically significant. However, the OLS results indicate that gender and age were significant in predicting saving behavior among Korean college students. Thus, Hypotheses 3 (gender) and 4 (age) were supported. Compared to younger students (age 18-20), older students (age 2124 or 25-29) scored higher on saving behavior. While female students tended to have more positive spending attitudes (Kim J., 2002), consistent with Jung and Yoon (2008), the saving score for females were higher than for males.

Table 3 also presents significant factors affecting the saving behavior of students with financial education. In the regression analysis, four dummy 
Table 3. OLS Results: Saving Behavior of Korean College Students

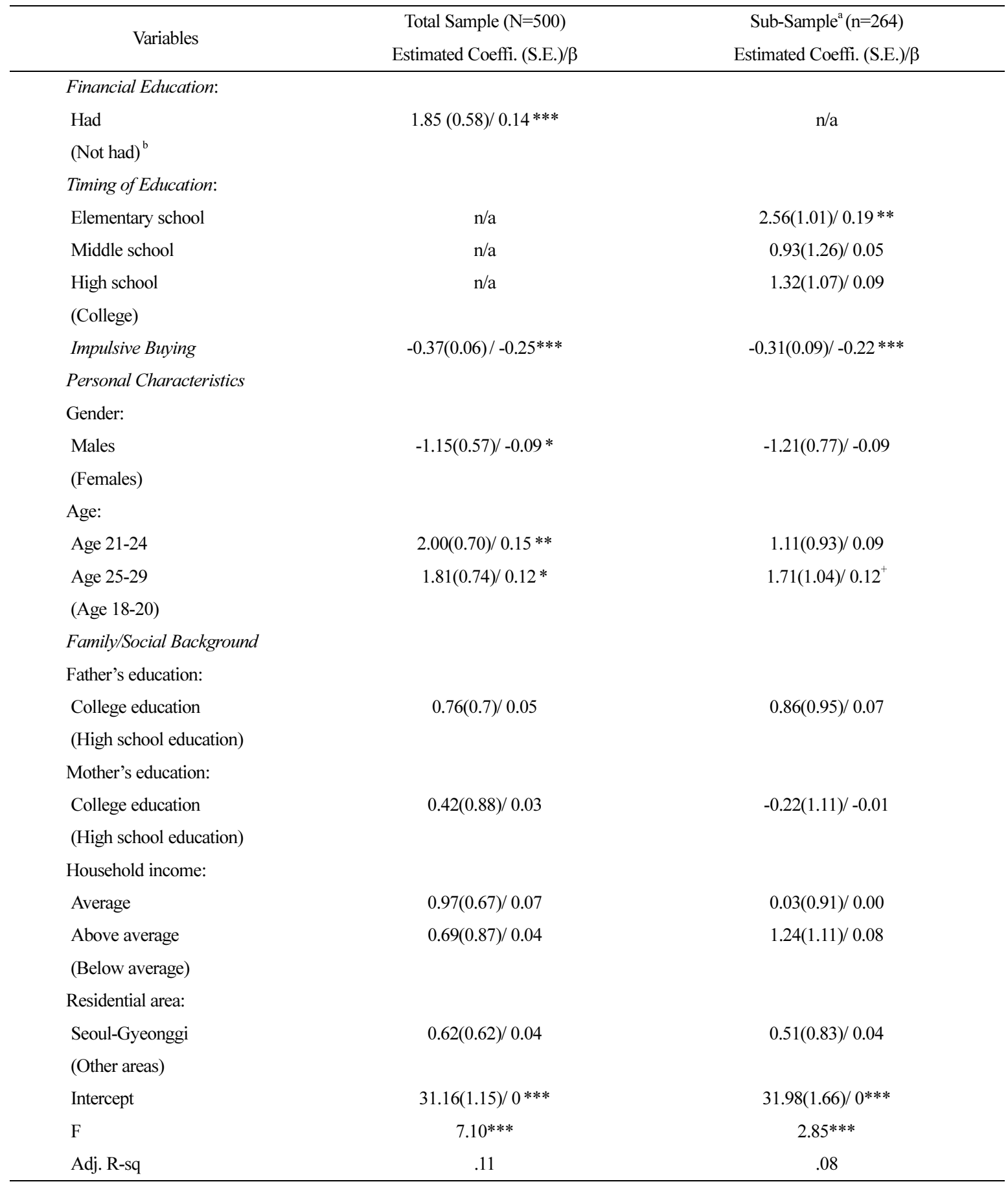

${ }^{+} p<.10 ; * p<.05 ; * * p<.01 ; * * * p<.001$

Note. ${ }^{\text {a }}$ denotes students with financial education experience; ${ }^{\mathrm{b}}(\mathrm{)})$ represent reference groups in multivariate analyses.

variables for the timing of financial education were included for the analysis of the sub-sample $(n=264)$.
The OLS results show that only the coefficient associated with elementary school was statistically 
significant and positive, indicating that students who received financial education during elementary years indicated more positive saving behavior than those who received money education in college. The findings suggest that having financial education during elementary school plays a significant role in determining saving behavior among students with financial education. Thus, receiving financial education as early as possible could significantly affect saving behavior of young adults in Korea.

For the total sample, older students (age 25-29) reported more positive saving behavior than younger students (age 18-20) among the sub-sample who reported financial education. Older students (age 25-29) show significantly higher saving score than younger students (age 18-20) in both the total and sub-samples, indicating that age is positively related to saving regardless of financial education. That is, the results suggest that, as students age, they develop more positive saving behavior; perhaps because they have more financial knowledge and experience. Similarly, as in the total sample, impulsive buying had a negative impact on the saving behavior of students with financial education. The results imply that regardless of financial education, higher levels of impulsive buying negatively influence saving behavior.

\section{DISCUSSION AND CONCLUSIONS}

The main purpose of this study was to explore the role of financial education and impulsive buying in influencing saving behavior of Korean college students. Descriptive results show that students who received financial education report more positive saving scores compared to students who did not receive financial education. Descriptive statistics suggest that financial education may explain why Korean college students differ in their saving behavior because those with financial education are more likely to express lower levels of impulsive buying and more positive saving behavior. Specifically, the OLS results show that all else being equal, students who had financial education in elementary school report more positive saving behavior than those who received education during college. Thus, this study concludes that financial education early in life can play an important role in influencing saving behavior in adult life.

According to the OLS results, high levels of impulsive money behavior, gender (male), and younger age (18-20) are negatively associated with Korean college students' saving behavior. Understanding how demographic, family, or money behavior factors are related to saving behavior for college students could guide educators and policymakers. They can target sub-groups such as freshmen, sophomores and/or males when they design financial education programs for college students. Because almost half of the sample had no financial education experience in school, consumer educators and financial professionals need to develop financial literacy programs for elementary, middle school, high school, and college students to encourage positive financial management and saving behavior.

Since Korean college students who did not have financial education have less positive saving behavior, it is important for consumer educators to develop financial education curricula for use in schools from elementary to secondary levels. In particular, considering the impact of education timing on saving behavior, it may be helpful for educators to design diverse programs that provide students from kindergarten to elementary age with financial knowledge through fun and interesting class activities. This financial knowledge appears to carry on to later in life and influence saving behavior during college.

A limitation of the study is that saving behavior is self-reported and may be skewed toward the positive end of the scale. While the convenience sample is not representative of all Korean college students, the size of the sample is robust. Despite the limitations, this study found the significant relationship between financial education and saving behavior among Korean college students. In particular, the findings of this study could provide an valuable information, suggesting that the effect of financial education on saving behavior was significant, and financial education early in life can play an 
important role in forming positive saving behavior in adult life.

A better understanding of the roles that financial education and educational timing play in saving behavior is an important area for future research. The findings of this study cannot be generalized to other populations because data were collected from only a few selected universities in Korea. Thus, future studies should utilize a larger pool of university students from different provinces so that the findings will provide more information on saving behavior among Korean college students. In addition, rather than relying on self-report, future research should incorporate more detailed information on saving behavior and actual amounts. Further, this study included only limited respondent demographics. The OLS results show that among personal, family/ social characteristics, only gender and age influence saving behavior in both the descriptive and multivariate analyses. However, by including more information of students' family and social characteristics and saving practices in the empirical models, the findings could provide additional insights for financial or consumer educators with respect to factors influencing saving behavior among Korean college students.

\section{REFERENCES}

Adams, C., Lown, J. M., \& Bailey, W. C. (1994). Attitudes toward the economic future: Implications for consumer education. Journal of the Home Economics Institute of Australia, 1, 11-18.

Bailey, W. C., \& Lown, J. M. (1993). A cross cultural examination of the aetiology of attitudes toward money. Journal of Consumer Studies and Home Economics, 17, 391-402.

Burgess, S. M. (2005). The importance and motivational content of money attitudes: South Africans with living standards similar to those in industrialised Western countries. South African Journal of Psychology; 35(1), 106-126.

Chung, K. (2008). Decrease in household savings rate and effectiveness of monetary policy. The Back of
Korea Economic Papers, 89, 3 January.

Dowling, N. A., Corney, T. \& Hoiles, L. (2009). Financial management practices and money attitudes as determinants of financial problems and dissatisfaction in young male Australian workers, Journal of Financial Counseling and Planning, 20(2), 5-13.

Edwards, E. A. (1993). Development of a new scale for measuring compulsive buying behavior. Financial Counseling and Planning, 4, 67-84.

Faber, R. J., \& O'Guinn T. C. (1992). A clinical screener for compulsive buying. Journal of Consumer Research, 19, 459-469.

Gresham, A. B., \& Fontenot, G. F. (1989). The differing attitudes of the sexes toward money: An application of the Money Attitude Scale. In P. J. Gordon and B. J. Kellerman (Eds.), Advances in Marketing (pp. 380-384). Cincinnati, Ohio: Southwestern.

Hayhoe, C. R. Leach, L., \& Turner, P. (1999). Discriminating the number of credit cards held by college students using credit and money attitudes. Journal of Economic Psychology, 20(6), 643-56.

Hong, E. (2005). A study on the money attitudes and the spending behaviors of middle, high, and college students. Journal of the Korean Home Management Association, 23(5), 103-121.

Jung, H., \& Yoon, H. (2008). A study on the attitude toward money by MAS (money attitude scale) and the dining-out behavior of undergraduates. Journal of Korean Home Economics Association, 46(6), 75-87.

Kim, H. (2005). Financial management behaviors of college students, Journal of the Korean Home Management Association, 43(7), 79-9.

Kim, J. (2002). Comparison of money and credit attitudes of female college students and housewives. Journal of Korean Home Economics Association, 40(3), 165-175.

Kim, J. H., \& Jeoung, H. J. (1996). A study on money beliefs and behaviors: An exploratory study of a cross-ethnic evaluation of MBBS. Journal of Wonkwang, 32, 521-535.

Kim, Y. (2005). A path analysis of attitudes towards credit cards, financial management practices, and sound credit card use among college students. Jour- 
nal of the Korean Home Management Association, 23(5), 15-26.

Lim, V. K. G., \& Teo, T. S. H. (1997). Sex, money and financial hardship: An empirical study of attitudes towards money among undergraduates in Singapore. Journal of Economic Psychology, 18, 369-386.

Lynn, R. (1993). Sex differences in competitiveness and the valuation of money in twenty countries. The Journal of Social Psychology, 133(4), 507-511.

Masuo, D. M., Kim. J. H., Malroutu, L., \& Hanashiro, R. (2002). Money beliefs and behaviors: A comparison of Asian and Asian American female college students. Journal of Asian Regional Association of Home Economics, 9, 223-227.

Masuo, D. M., Malroutu, Y. L., Hanashiro, R., \& Kim, J. H. (2004). College students' money beliefs and behaviors: An Asian perspective. Journal of Family and Economic Issues, 25(4), 469-481.

Moore, M., \& Carpenter, J. M. (2009). The impact of college student money attitudes on credit responsibility. College Student Journal, 43, 1116-1124.

Norvilitis, J. M., Merwin, M. M., Osberg, T. M., Roehling, P. V., Young, P., \& Kamas, M. M. (2006). Personality factors, money attitudes, financial knowledge, and credit-card debt in college students. Journal of Applied Social Psychology, 36(6), 1395-1413.

Özgen, Ö., \& Bayoğlu, A. S. (2005). Turkish college students' attitudes towards money. International Journal of Consumer Studies, 29, 493-501. DOI: 10.1111/j.1470-6431.2005.00417.x

Plummeting savings rate. (2012, May 31). The Korea Herald. Retrieved from: http://view.koreaherald.com/ kh/view.php?ud $=20120531000857 \& c p v=0$

Ramstad, E. (2010, November 8). The miracle is over. Now what? The Wall Street Journal Report, R1 \& R4.
Roberts, J. A., \& Jones, E. (2001). Money attitudes, credit card use, and compulsive buying among American college students. The Journal of Consumer Affairs, 35(2), 213-240.

Roberts, J. A., \& Sepulveda, C. J. M. (1999). Demographics and money attitudes: A test of Yamauchi \& Templer's (1982) money attitude scale in Mexico. Personality and Individual Differences, 27, 19-35.

Spinella, M., Yang, B., \& Lester, D. (2007). Development of the Executive Personal Finance Scale. International Journal of Neuroscience, 117(3), 301-313.

Sybrowsky, J. P. (2007). Paths toward impulsive buying: The effect of credit use and debt avoidance on the paths between money attitudes and impulsive buying among U.S. college students. Unpublished master's thesis, Brigham Young University, Provo, Utah.

Tang, T. L. (1992). The meaning of money revisited. Journal of Organizational Behavior, 13, 197-202.

Tang, T. L. (1993). The meaning of money: Extension and exploration of the money ethic scale in a sample of university students in Taiwan. Journal of Organizational Behavior, 14, 93-99.

Tung, R. L., \& Baumann, C. (2009). Comparing the attitudes toward money, material possessions and savings of overseas Chinese vis-à-vis Chinese in China. The International Journal of Human Resource Management, 20, 2382-2401.

Yamauchi, K., \& Templer, D. (1982). The development of a money attitude scale. Journal of Personality Assessment, 46, 522-528.

Received March 29, 2012

Revised June 12, 2012

Accepted June 16, 2012 